\title{
The Formation of Shipping Conference and Rise of Shipping Alliance
}

\author{
Mariner Wang ${ }^{1}$ \\ ${ }^{1}$ Graduate School of Management, Ritsumeikan Asia Pacific University, Japan \\ Correspondence: Dr. Professor Mariner Wang, Graduate School of Management, Ritsumeikan Asia Pacific \\ University, Japan
}

Received: August 5, 2015

Accepted: August 31, $2015 \quad$ Online Published: September 4, 2015

doi:10.5430/ijba.v6n5p22

URL: http://dx.doi.org/10.5430/ijba.v6n5p22

\begin{abstract}
In order to encourage competition in international shipping and growth of U.S. exports, the Senate and House of Representatives of the U.S.A. in Congress assembled in 1988. In the assembly, the Shipping Act of 1984 was amended and instead, the OSRA (Ocean Shipping Reform Act) of 1998 which modernizes and deregulates the international ocean shipping business was enacted.

The biggest change is shippers are allowed to sign the Service Contract (S/C) directly with individual carrier (but not the alliance). After the implementation of OSRA of 1998, there has been drastic increase in the number of S/Cs, in addition, the volume of cargo moving under service contracts has been ever increased. For this, the existence of shipping conference became meaningless and then totally appear and out of the market.

OSRA of 1998 are regarded as the catalyst contributing to the restructuring of the liner shipping industry. It has led to the formation of shipping alliance in terms of vessel-sharing and space charters.

The activities of shipping alliances between liner carriers have been increasing intensively since the last two decades, satiating with a whole new requirement of shippers stemmed from the industrial globalization.
\end{abstract}

Keywords: Suez Canal, Shipping Conference, Open Conference, Close Conference, Alexander's Report, Shipping Alliance, international shipping, Service Contract (S/C), OSRA of 1998, CKYH, The Global Alliance, Grand Alliance, The New World Alliance, P3

\section{The Emergence of Shipping Conference}

Shipping conferences are organizations of vessel operators who serve similar markets. They form cartels to both regulate competitions among themselves and protect their market from outsiders.

Shipping conferences agrees to provide regular sailings on a scheduled basis, even though during certain low seasons, the total amount of cargo offered by all shippers might be small. Liner companies from different nations can belong to the same conference.

The ocean shipping conferences were form in the trade between England and its colony India in the $19^{\text {th }}$ century. The opening of the Suez Canal (Note 1) and the introduction of the steamship, that was more productive than the sailing ship, had produced an excess in vessel tonnage.

With an aim to securing the big pile from the market, ocean freights dropped below costs as ship owners engaged in "cut-throat" competition. Under the untoward circumstance, competitors will be forced to drop out of the market and the irregularities in sailings upset many shippers who wanted stable services.

Strong arguments (con party) had been made that the United Stated should not permit shipping conferences to exist, while strong arguments (pro party) in support of shipping conferences had also been made. In the Merchant Marine Act of 1916 (Note 2), America Congress, following the advice of what was called the Alexander Report, allowed shipping conferences to call at U.S. ports, although it placed some restrictions on their operations.

This pattern has continued to the present. There is a compromise that recognized both the need for shipping cartels and the potential evils associated with them.

Here is an example of how a conference might organize. Assume "conference A" operates from Asia to the west coast of North America. Each has a container vessel and a round-trip takes 24 days. They agree to deploy four 
vessels (each shipping company deploys one vessel) to provide four sailings per week and not wait for more cargo. They would charge the same rates and pay the same commissions to NVOCCs (Note 3).

At end of year, they would "pool" profits, meaning, for example, that each of the four would be guaranteed a minimum of, say, $20 \%$ of the four vessels' combined profits. In order to protect themselves from outside competitors, conference A would give customers (exporters, importers, NVOCCs) who agreed to use the conference exclusively a $10 \%$ rebate. Basically, this is the win-win policy, both parties benefit from the agreement.

\section{Open and Closed Conference}

Until World War II (1939 - 1945), the United Kingdom held overwhelming power over any other country and region in the world in shipping industry. With a view to controlling the shipping market, the Closed Conference or Regulated Conference was organized by the British and British-related shipping companies.

In order to compete against the Closed Conference, in 1914 the Alexander's Report pertaining to merchant marine and fisheries was submitted by the House of Committee in the Congress of the United Stated. Based on the Alexander's Report, Merchant Marine Act of 1916 was enacted.

Because of the stipulation of the Act, the "Open Conference" was formally organized by the American shipping lines as well as the foreign shipping lines entering and leaving the ports in the United States. At the same time, the Sherman Anti-Act of 1890 (Note 4), which stipulated that shipping conference is against the law, was replaced, and shipping conference became legalized since then.

The big difference between Open Conferences and Close Conference is the former must let any line to join, while the latter is more restrictive, and does not allow outsiders to join. Nowadays, the membership of most conferences is closed. The characteristic of the Closed Conference is that it is much more effective in monopolizing the trade lanes that they serve. This raises the issue pertaining to how strong the controls are that the shipping conference has over their member lines. This varies year by year and market by market.

Here is an example of how the conference exerts its strength over its competitors. At one time, when faced with competition from an outsider, the conferences would assign one of the their vessels to be a "fighting ship" which would follow the outside line's vessel from port to port by offering to carry the cargo for less than whatever the outsider charged.

For about two decades, the developing nations have forced conferences serving their ports to allow native-flag vessels to enter the conference, because one of the developing nations' complaints has been that the conferences represent the established powers' commercial needs. The United States does not allow closed conferences to serve its ports.

Some shipping conferences exercise almost military control over the members and their members' practices, whereas in other shipping conferences almost no member is charging the conference rates. It is always the case that when demand for shipping space is high, all shipping lines charge the published rates based on the tariff and discipline is good.

However, when the shipping market declines, some member lines get hungry and begin cutting rates, using a practice known as "Independent Action (IA)" (one of the difficulty tasks confronting a shipper's traffic manager is to determine how disciplined the conference is at any one time). This is the game played by the shipping lines in order to secure the cargoes during the recession seasons.

\section{Asian Ship Owners' Forum (ASF)}

Asian Shipowners' Forum (hereinafter referred to as ASF) was founded in April 1992 when its first meeting was held at Japan Shipping Club in Tokyo. As one of the important shipping organizations in the world, ASF consists of eight members from the shipowners' associations of Asia Pacific nations, i.e. Australia, China, Hong Kong, India, Japan, Korea, Chinese Taipei and Federation of ASEAN Shipowners' Associations which consists of Indonesia, Malaysia, Myanmar, the Philippines, Singapore, Thailand and Vietnam.

Following the principle agreed at the first ASF meeting, the venues for the annual meetings have been conducted on a rotational basis by the members from the North to South in geographical order. Similarly, the chairman of the ASF is on the same rotational basis. In addition, this chairman is also the convener for the ASF chairman's meeting, which is as the board of the ASF.

In ASF, five standing committees (S-5 Committee) are formed and each committee is headed by a nominated chairman. They are the Shipping Economics Review Committee (SERC), Ship Recycling committee (SRC), 
Seafarers Committee (SC), Safe Navigation \& Environment Committee (SNEC) and Ship Insurance \& Liability Committee (SILC). The work is basically done between the annual ASF meetings, with each committee being committed to convene at least one meeting a year.

In viewing of the growing importance of the ASF, it was decided at the 16th annual meeting in Korea in May 2007 that the permanent office for the ASF should be set up and the location of the ASF office was chosen to be set up in Singapore. After the ASF 2nd Chairmen's Meeting held in July the same year, the ASF opened its office Singapore in October 2007.

With an aim to stabilizing the ocean freight offered by the shipping companies deploying the vessels in the trade lane, Trade Stabilization Committee (TSC) was organized under ASF. There is annual general meeting being held in member countries by rotation.

Since the establishment of ASF in 1992, it has played a pivotal role in enhancing the mutual understanding and friendly relationship between shipping line members. Through the general meeting and S-5 Committee, Asian Ship owners are exchanging the opinions regarding the crucial issues in dealing with the shipping movement. In addition, Executive Committee, Rate Committee, Ethics Committee, and Neutral Body are also organized in order to tackle with the operation of the shipping conference.

Secretariat is responsible for the daily affairs including conference agreement, conference member application, rebate, dual rate system, tariffs, cargo volume statistics, conference budget and expense, and under the instruction and order of the chairman of the conference to execute the decision issues unanimously agreed by conference members.

According to the reliable shipping statistics, the ASF membership together is estimated to control about $50 \%$ of the world merchant fleet today.

\section{Intra-Asia Discussion Agreement (IADA)}

Because of the enactment of Shipping Act of 1984 (Note 5), the functions of the shipping conferences was constrained, in addition, due to the over tonnage of the vessels being deploying in the trade lanes which generated the cutthroat competition, the pricing power of the conference members became relatively weak, finally, the Conference Cartel became a mere name.

In viewing of the excessive competition in ocean freight and in order to stabilize the market, the discussion agreement (also called stabilization agreement) based on opinions exchanging between conference and non-conference members was made since the late 1980. Based on the discussion agreement, the Intra-Asia Discussion Agreement (IADA) was formed in 1992.

Basically, IADA is the "discussion agreement" but not the shipping conference which bears restrictions on the shipping lines joining the conference. However, from the point view of shippers, IADA is rather a "pricing decision organization" than a discussion agreement. In fact, shippers have been always standing in opposition against IADA.

For example, in middle 2009, IADA shipping lines have announced a rate increase of US\$75 per TEU (Twenty Equivalent Unit), namely a 20 -foot container, on all intra-Asia trade lanes excluding the cargoes to and from Japan that will take effect from September 1, and another increase of $\$ 100$ per TEU on all cargoes to and from Japan starting October 1 when cargo volumes picked up in the third quarter of 2009.

The increases in ocean freights will be made on top of current rates and will be separate from the full recovery of surcharges applied at time of shipment, including the application of full floating bunker surcharges. 
Table 1. Members of IADA (as of November 2011)

\begin{tabular}{llllll}
\hline No. & Shipping Co. & Country & No. & Shipping Co. & Country \\
\hline 1 & APL & Singapore & 16 & MCC Transport & Singapore \\
\hline 2 & Biendong & Vietnam & 17 & MOL & Japan \\
\hline 3 & CNC $*$ & France & 18 & NYK & Japan \\
\hline 4 & CMA CGM & France & 19 & OOCL & Hong Kong \\
\hline 5 & COSCO & China & 20 & PIL & Singapore \\
\hline 6 & Evergreen & Taiwan & 21 & RCL & Thailand \\
\hline 7 & Gemadep & Vietnam & 22 & Samudera & Singapore \\
\hline 8 & Gold Star & Hong Kong & 23 & Sinokor & Korea \\
\hline 9 & Hanjin & Korea & 24 & SITC & China \\
\hline 10 & Hapag-Lloyd & Germany & 25 & STX Pan Ocean & Korea \\
\hline 11 & Heung A & Korea & 26 & UASC & Koweit \\
\hline 12 & Hyundai & Korea & 27 & Vinalines & Vietnam \\
\hline 13 & Interasia & Japan & 28 & Wan Hai & Taiwan \\
\hline 14 & K Line & Japan & 29 & Yang Ming & Taiwan \\
\hline 15 & Korea Marine & Korea & & &
\end{tabular}

Note: $*$ CNC (Cheng Lie Navigation) was merged by MA CGM in 2007.

$\mathrm{PIL}=$ Pacific International Lines. $\mathrm{RCL}=$ Regional Container Lines.

Source: IADA Tokyo.

The reason for the rate increase is that all shipping lines have been severely impacted from the global economic recession starting in the fourth quarter of 2008 triggered by the Lehman Shock in September 2008. During this period, all shipping lines have been hit by a sharp drop in cargo volumes and a sharp drop in moving rate levels. As a result, all carriers in this market have been operating at unprofitable levels for the past several months and risk being unable to maintain current services.

Intra-Asia shipping lines have been seeking ways to turn around negative contributions on their services. Annual meeting of senior executives in the IADA is to be taken place to review market conditions and carriers' ability to meet shippers' demands in the dynamic intra-Asia market. As of December 2009, IADA is composed of 29 shipping lines from 13 countries as shown in Table 1 .

\section{Conference's Market Strategies}

\subsection{Deferred Rebate System}

It is referred to the return of a portion of the freight charges by a carrier or a conference shipper in exchange for the shipper giving all or most of his shipments to the carrier or conference over a specified period of time (usually 6 months). Payment of the rate is deferred for a further similar period, during which the shipper must continue to give all or most of his shipments to the rebating carrier or conference.

The shipper thus earns a further rebate which will not, however, be paid without an additional period of exclusive or almost exclusive patronage with the carrier of conference. In this way, the shipper becomes tied to the rebating carrier or conference. Although, the system is illegal in U.S. foreign commerce, it generally is accepted in the ocean trade between foreign countries.

\subsection{Dual Rate System}

This rate system is offered by the conference members. The system was approved based on the revised Shipping Act of 1916. However, the maximum rate discount should be 15 percent, and the shipping lines are obliged to file the newly published rates to FMC (Federal Maritime Commission) (Note 6) classified as tariffs when published. 
Shippers during a fixed period, by never using the non-conference shipping lines, keep utilizing the conference are granted to be offered the cheaper rate compared with those shippers who do not have signed contract with the conference member lines.

However, shippers are obliged to pay the penalty for breach of contract should they used the non-conference, in addition, they will be refused for further contract signing.

As shippers can discontinue the contract after the expiry of the contract, or can cancel the contract by pre-notice, the binding force is weaker compared with Deferred Rebate System.

Fair Trade Commission admits exporters to load their export cargo on non-conference with no penalty from the conference should the transaction is made under FOB (Free on Board) term. Namely, ocean freight is to be paid by consignee (importer) and the consignee holds the right in choosing the shipping line.

In the United States, the system, like Deferred Rebate System, is banned under the Shipping Act of 1984.

\subsection{Three Decker System}

This is the rate system adopted by the conference shipping lines deploying vessels on the Japan/Europe lane since May 1964. It is based on the Dual Rate System, those contracted shippers, though under the instruction of consignee to load their cargo on non-conference on FOB basis, refuse to load non-conference and instead loading on conference shipping lines are to be granted for additional 2.5 percent discount from contract rate.

The system applies to the non-contract shippers being offered the non-contract rate; those shippers exporting cargo under FOB term; those shippers signing the contract with the conference. This system is named the Three Decker System.

\subsection{Fidelity Rebate System}

This is the system replacing the Three Decker System adopted by the Japan/Europe trade lane since October 1, 1966. Those shippers having fulfilled the promise loading cargo on the conference, though being instructed by consignee to load on non-conference under the FOB term (Note 7), are granted 2.5 percent rebate from the contracted total freight sooner after every four months.

Under the circumstances, shippers, after each four months' loading, are supposed to submit the "claim for payment of fidelity rebate" to the conference.

Fidelity Rebate System is different to Deferred Rebate System as the rebate is to be refunded sooner after the expiry of each contracted period. Because the binding force on shippers is weaker, it is highly evaluated as the countermeasure against the non-conference.

\subsection{Guarantee Contract System}

This is the contract under the requests of shippers. Shippers are obliged to load their cargo on the shipping conference during a fixed period on a fixed trade lane by being offered the fixed ocean freight. The ocean freight is higher than the tariff rate, however, the shipping conference promises not to increase the ocean freight (ocean freight remains the same as contracted) when the market is on the up when space becomes tight (Note 8).

\section{Relationships among Shipping Conference Members}

Shipping conferences exist throughout any sea in the world, though they are of varying strengths and frequently reorganized or realign. The most usual grouping is vessels that sail between two port areas, say, the Asian ports and ports in U.S. West Coast.

Sometimes the shipping conference covers shipments in both directions, sometimes only one direction only, as some members may return by a triangular rather than a straight route, subject to market demands. The reason is that some shipping lines might have their vessels go back and forth, say, between ports in U.S. West Coast and Australia, whereas other lines might deploy vessels from ports in U.S. West Coast to Australia, but then their vessels will sail to ports in Japan, and then back to the West Coast.

The former shipping lines would probably belong to two alliances, say, the U.S. West Coast to Asia Conferences and the Asia to U.S. West Coast Conferences, whereas the second lines might belong to three conferences: the U.S. West Coast to Australia conference; the Australia to Japan conference, and the Japan to U.S. West Coast conference. Often the same carrier belongs to several conference $\mathrm{s}$ and sometimes these conferences compete with each other such as from South Atlantic ports to the ports in the United Kingdom and from U.S. Gulf ports to the ports in the United Kingdom. 
Conference members attempt to eliminate competition among themselves as much as possible. They offer uniform, or near-uniform, service to shippers. They pay equal commissions to NVOCCs, and so on. Nonetheless, because of vagaries in the flow of cargoes, it might be that in the course of a year, the traffic carried would not be divided equally carried by each line. Traffic or profits are sometimes pooled and, say, at the end of the year, the conference would examine the bookings of all members and redistribute the revenues or profits according to some previously agree-on formula, say, each member gets at least $20 \%$ but no more than $35 \%$ of the revenues, or the profits.

Experience has shown that conference members are not always honest with each other. Often they will allow a shipper to state a lower weight or lesser classification of his shipment on order to pay lower charges than the conference tariffs and classifications call for. In order to prevent the behavior from happening, conferences hire outside "policing" agents to spot check the members' honesty and reduce the problems of understating weights or under classifying cargo. This is called self-policing.

\section{Contracts between Conference and Shippers}

Shippers' contracts with alliances vary with the alliances and its relative monopoly strength. For alliances not serving U.S. ports, the shippers agree to give the alliance vessel lines all of their business in the area served by the alliance.

However, there are two exceptions where cargoes rendered by shippers will be rejected by shipping conference. That is, when the shipping conference has no pace available or when the shipment is larger than a certain size (i.e., so large that it might be feasible for the shipper to charter an entire vessel).

\subsection{Service Contract $(S / C)$}

It was permitted under the Shipping Act of 1984 and the contract drawn up between shipping conference and specific shippers. The S/C consists of a commitment by the shipper to shipping conference a minimum volume of cargoes, usually expressed in TEU with ocean freight levels indicated on intermodal, point to point, or port to port basis. The $\mathrm{S} / \mathrm{C}$ is for a specific period of time. The carrier or shipping conference is obligated to guarantee regular service, say, a particular port rotation and specialized equipment.

There are also clauses for penalty should the shippers do not live up to its commitment due to, say, loss of overseas sales. Most S/C cover containerized cargo, and many have a most-favoured shipper clause, meaning that if the shipping conference gives another similarly situated (i.e., with similar tonnages, destinations, and frequencies) shipper a better rate, the initial contracting shipper will also get it. Most agreements are about twelve pages long.

The $\mathrm{S} / \mathrm{C}$ is initially negotiated, and a sealed copy is sent to the FMC, then a summary of the terms appears in a publication available to all parties, including shippers and shipping lines. Other shippers similarly situated may demand the same terms.

\section{Ocean Shipping Reform Act (OSRA) of 1998}

With an aim to encouraging competition in international shipping and growth of United States exports, and for other purposes, the Senate and House of Representatives of the United States of America in Congress assembled in 1988 amended or modified the Shipping Act of 1984 and instead, the OSRA (Ocean Shipping Reform Act) (Note 9) of 1998 which modernizes and deregulates the international ocean shipping business was enacted.

The major regulatory changes made by OSRA of 1998 were aimed at promoting a more market driven, efficient liner shipping industry (Note 10). After years of operations under this statute, indications are that it generally is achieving this objective. The liner shipping industry has been experiencing dynamic structural changes over the past several years. OSRA of 1998 was enacted in full recognition of these changes, and has helped to foster their continuing evolution. For this, the FMC developed comprehensive regulations to implement OSRA of 1998, and has altered its approach to industry oversight to facilitate the attainment of OSRA of 1998 basic policy.

OSRA of 1998 is the most significant legislative change to affect the United States containerized liner shipping industry in fourteen years. The new law permits confidential contracting in international ocean shipping; privatizes common carrier tariff publication; retains the antitrust exemption for the ocean liner industry; and eliminates many of the common carrier antidiscrimination provisions that smaller shippers have relied upon for much of this century to ensure non-discriminatory competitive access to international ocean carrier services and, correspondingly, access to overseas markets. The new law continues and enhances the protections afforded to shipper's associations in international trade and their favoured position under the law.OSRA of 1998 took effect on May 1, 1999. In response to the new law, numerous shippers have either formed or joined shippers' associations in order to ensure that they can remain competitive in the global marketplace in ensuring access to competitive ocean transportation services. 
Numerous pro-competitive reforms enacted under OSRA of 1998 to increase industry market responsiveness focused on service contracting. That is the ability of shippers to sign the Service Contract $(\mathrm{S} / \mathrm{C})$ not open to the public by dealing with individual carrier (not the alliance), the elimination of the "me-too" requirement for similarly situated shippers, and the confidentiality of certain commercially sensitive service contract terms have fostered a shift to contract carriage.

After the implementation of OSRA of 1998, there has been drastic increase in the number of S/Cs. In addition, the volume of cargo moving under $\mathrm{S} / \mathrm{Cs}$ has been ever increased. It was due, in part, to the flexibility and confidentiality of individual S/C. Most shippers presently are negotiating "one-on-one" with individual shipping lines for confidential S/Cs, instead of negotiating with "rate-setting" shipping conferences (See Figure 1, Figure 2).

Nonetheless, many S/Cs continue to be linked to tariffs for accessorial charges, surcharges (Note 11), and certain rules. At the same time, as triggered by the enactment of OSRA of 1998, NVOCCs have the authority to engage in service contracting with shipper directly, so as to put them on equal footing with ocean carriers, namely, Vessel-Operating Common Carriers (VOCCs). Due to the implementation of OSRA of 1998, the existence of shipping conference became meaningless and then totally appear and out of the market gradually in the Asia/North America trade lane.

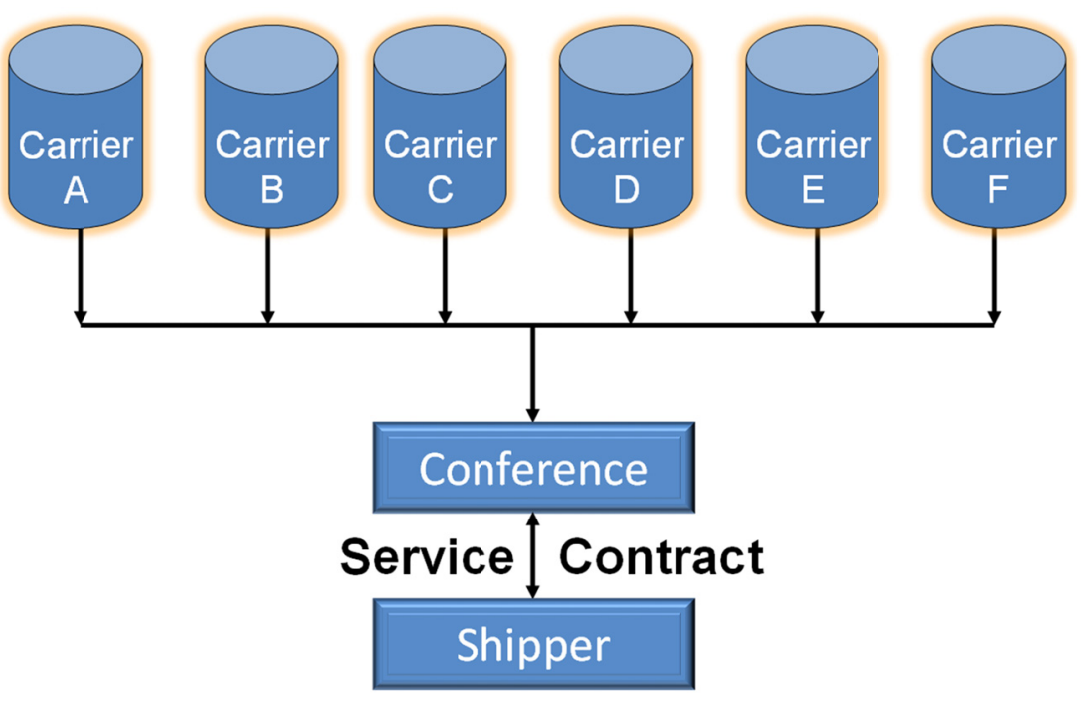

Figure 1. Status of service contract before OSRA of 1998 


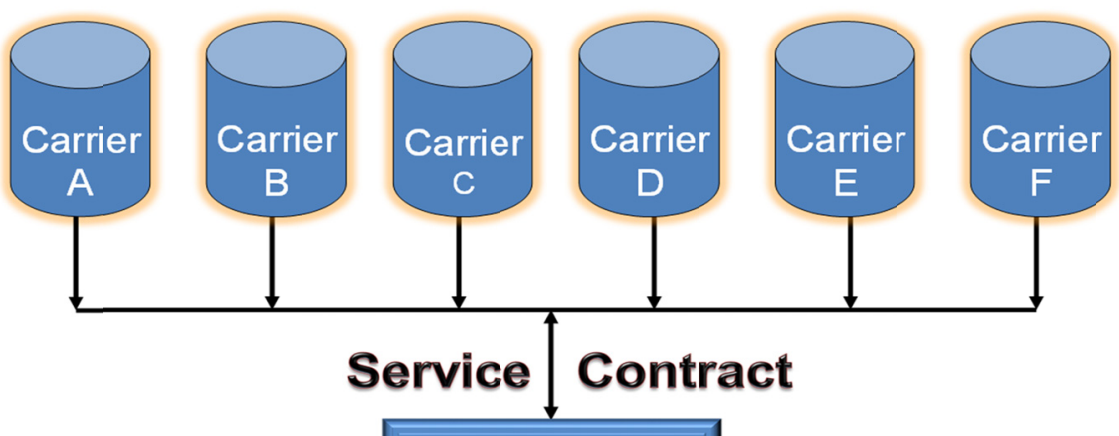

Shipper

Figure 2. Status of service contract after OSRA of 1998

\section{The Rise of Shipping Alliance}

Shipping alliances have become an industry trend during the recent years. The emergence of global markets, the improved service of non-conference carriers, and the deregulatory nature of OSRA of 1998 are catalysts that have contributed to the restructuring of the liner shipping industry. This has led to a de-emphasis of traditional conferences and a dramatic increase in efficiency-enhancing operational types of agreements, such as vessel-sharing and space charters.

\subsection{The Development of Shipping Alliance}

The consolidation in the shipping industry has been carried out through internal growth with the launch of large expansion capacity plans (95 new Post-Panamax (Note 12) during the period of 1995-1999), external growth (mergers and acquisitions) and co-operation with the establishment of new partnerships referred as strategic alliances.

The first strategic alliance-Global Alliance among OOCL (Hong Kong), MOL (Japan), APL (USA), Nedlloyd (Holland) appeared in the end 1995. Two years later in 1997, 60/70\% of the services on the main East-West trade lanes were supplied by the four main strategic alliances, namely, Global Alliance, Grand Alliance, Maersk-Sea Land and TRICON that put together 13 of the 20th first ship-owners. The members of the four alliances in 1995 are shown on Figure 3.

In theory, alliance members are not involved in price-setting but in the rationalization of capacity through such schemes as vessel, terminal and equipment sharing, joint-scheduling, slot-chartering. Since the establishment of Shipping Alliance in 1995, the members have been reshuffling through 1998 and up to 2010 (See Figure 4).

In 1998, five Shipping Alliances came into existence in the world. They are New World Alliance, Grand Alliance, Maersk Sea Land, TRICON and Sino-Japan Alliance. Namely, two new alliances came into being in 1998.

Strategic alliances have become an essential tool for large carriers to extend their service ranges in the global markets. The development of strategic alliances is ultimately crucial to the liner industry, especially based on a perspective of the booming market-Asia.

Over the last decade, Shipping Alliances have been active in increasing their product offerings and reducing the running costs. Some of the alliances members have revised their market strategies by withdrawing the membership of their current alliance and instead joining other alliances, while some Shipping Alliances been active in trade lanes cooperation. 
For example, in early 2006, Grand Alliance (GA) and The New World Alliance (TNWA) began to jointly operate on key trades. This co-operation has significantly broaden the respective alliances' capabilities, network coverage and schedule frequency.

The member lines of the then Grand Alliance (Hapag-Lloyd, MISC, NYK, and OOCL) and The New World Alliance (APL, Hyundai and MOL) agreed to exchange slots (Note 13) in the Asia-Europe and Asia-Mediterranean trades, and introduce a new jointly-operated loop on the Asia-East Coast of North America, via Panama trade. In addition, the members of the two alliances further expanded the scope of their co-operation through other joint services.

1995

1998

\begin{tabular}{|c|c|}
\hline $\begin{array}{l}\text { Global Alliance } \\
\text { OOCL (Hong Kong) } \\
\text { MOL (Japan) } \\
\text { APL (USA) }\end{array}$ & $\begin{array}{l}\text { New World Alliance } \\
\text { APL/NOL (USA/Singapore) } \\
\text { MOL (Japan) } \\
\text { Hyundai (Korea) }\end{array}$ \\
\hline Grand Alliance & Grand Alliance \\
\hline P\&OCL (UK) & P\&O Nedlloyd (UK) \\
\hline Hapag-Lloyd (Germany) & OOCL (Hong Kong) \\
\hline NYK (Japan) & Hapag-Lloyd (Germany) \\
\hline NOL (Singapore) & NYK (Japan) \\
\hline $\begin{array}{l}\text { Maersk/Sea-Land } \\
\text { Maersk (Denmark) }\end{array}$ & $\begin{array}{l}\text { Maersk/Sea-Land } \\
\text { Maersk (Denmark) } \\
\text { Sea-Land (USA) }\end{array}$ \\
\hline Sea-Land (USA) & $\begin{array}{l}\text { TRICON } \\
\text { Hanjin (Korea) }\end{array}$ \\
\hline TRICON & $\begin{array}{l}\text { DSR-Senator (Germany) } \\
\text { Cho Yang (Korea) }\end{array}$ \\
\hline $\begin{array}{l}\text { Hanjin (Korea) } \\
\text { DSR-Senator (Germany) } \\
\text { Cho Yang (Korea) }\end{array}$ & $\begin{array}{l}\text { Sino-Japan Alliance } \\
\text { COSCO (China) } \\
\text { K Line (Japan) } \\
\text { Yang Ming (Taiwan) }\end{array}$ \\
\hline
\end{tabular}

Figure 3. Generation of strategic alliances on Asia-North America West Coast trade lane (1995-1998) 


\begin{tabular}{|c|c|}
\hline $\begin{array}{l}\text { The New World Alliance } \\
\text { APL/NOL (USA/Singapore) } \\
\text { MOL (Japan) }\end{array}$ & $\begin{array}{l}\text { The New World Alliance } \\
\text { APL (Singapore) } \\
\text { MOL (Japan) }\end{array}$ \\
\hline \multirow{5}{*}{$\begin{array}{l}\text { Grand Alliance } \\
\text { P\&O Nedlloyd (UK) } \\
\text { OOCL (Hong Kong) } \\
\text { Hapag-Lloyd (Germany) } \\
\text { NYK (Japan) }\end{array}$} & Grand Alliance \\
\hline & Hapag-Lloyd (Germany) \\
\hline & NYK (Japan) \\
\hline & OOCL (Hong Kong) \\
\hline & MSC (Switzerland) \\
\hline \multirow{2}{*}{$\begin{array}{l}\text { Maersk/Sea-Land } \\
\text { Maersk (Denmark) } \\
\text { Sea-Land (USA) }\end{array}$} & Maersk (Denmark) \\
\hline & CMA-CGM (France) \\
\hline \multirow{3}{*}{$\begin{array}{l}\text { TRICON } \\
\text { Hanjin (Korea) } \\
\text { DSR-Senator (Germany) } \\
\text { Cho Yang (Korea) }\end{array}$} & Evergreen (Taiwan) \\
\hline & CSCL (China) \\
\hline & CKYH Alliance \\
\hline \multirow{4}{*}{$\begin{array}{l}\text { Sino-Japan Alliance } \\
\text { COSCO (China) } \\
\text { K Line (Japan) } \\
\text { Yang Ming (Taiwan) }\end{array}$} & Hanjin (Korea) \\
\hline & $\operatorname{cosco}$ (China) \\
\hline & K Line (Japan) \\
\hline & Yang Ming (Taiwan) \\
\hline
\end{tabular}

Figure 4. Shift of strategic alliances on Asia-North America West Coast trade lane (1999-2010)

\subsection{The Birth of CKYH Alliance}

The activities of shipping alliances between liner carriers have been increasing intensively since the last two decades, satiating with a whole new requirement of shippers stemmed from the industrial globalization. In 1996, a specific cooperation with slot charter and exchange on ocean going services began among K Line (Japan), Yang Ming (Taiwan) and COSCO (China). Gradually, those three world leading carriers had joint fleet agreement on the main trade services before the end of the last century.

In early 2003, Hanjin (Korea) formally allied with COSCO, Yang Ming and K Line to form CKYH Alliance, the world's largest strategic alliance. CKYH has been aggressively accelerating their expansions since its establishment. Together with the other four Shipping Alliances or mega carriers, the world five Shipping Alliances totally shared $45 \%$ of the world container cargo in 2004.

With an aim to improving the service provided to customers (exporters and importers) in the trade lanes, in May 2006, CKYH reformed in PNW (Pacific Northwest) service routes through new joint operations and upgrading of vessels with a total of 4 loops. COSCO and Hanjin join hands to run CH-PNW South Loop and CH-PNW North Loop. Each carrier deployed four 5500TEU containerships, two each in the respective loops. CH-PNW South and North Loops have accelerated PNW transit time, linking South China to North America West Coast in 11 days and Shanghai to Seattle in 10 days respectively. 
In November, 2007, CKYH restructured its Asia/European trade lanes by rearranging port rotations, upgrading vessels ranging up to $10,000 \mathrm{TEU}$, and inaugurating 2 more services. This will further enhance ability of CKYH to provide shippers and consignees with more frequent calling schedules in Asia side and more vessel space as the cargo demand from Asia to North Europe is steadily growing.

On November 13, 2009, CKYH, with an aim to achieving a controlled operation cost and addressing to the energy consumption for a better practice in corporate citizenship, announced future scheme in certain loops with a super-slow-steaming program.

Further, on April 15, 2010, CKYH 2010 Summit Meeting was held in Zhenjiang, China. At the annual CKYH Summit meeting, CKYH Alliance members re-affirmed to further strengthen the collaborative partnership and confirmed the direction of future development.

In addition, CKYH renamed itself as "CKYH-the Green Alliance" which embodies its strong determination on environmental protection. All alliance members will take further measures such as eco-steaming for energy-saving and emission reduction, etc. (Note 14).

At the same time, all members will take positive action to take full advantage of regional tranship hubs, build up extensive feeder networks, extend cooperation to the North/South trades \& new emerging markets, widen the scope of cooperation to other sections of the Transport Chain by optimizing the alliance's resources such as terminals, chassis, inter-modal facilities and equipment.

In April 2011, the CKYH-the Green Alliance began to restructure and upgrade its all-water services from Asia to the U.S. East Coast. The alliance, which operates five weekly loops (AWE-1 through AWE-5), will increase the capacity of the ships on the AWE-5 service which is currently operated by Hanjin Shipping and Yang Ming with nine ships with capacities of 4,300 TEUs each. In addition, CKYH-the Green Alliance also changed the ports of call on the AWE-2 and AWE-3 service by adding calls at Norfolk and Shanghai respectively. The nine vessels will be replaced with nine ships of 5,500 TEUs apiece, of which each of the partners will deploy three.

In addition, CKYH-the Green Alliance and Evergreen Line has enhanced their frequency of service loops, expedition of delivery terms and full scale of port coverage in their services, and have agreed to strengthen their cooperation in Asia-Europe and Asia-Mediterranean trade lanes from the second quarter of 2012 (Note 15).

Although Evergreen will not be joining CKYH-the Green Alliance, the carrier will coordinate with each other to provide more intensive sailings to the level of eight service loops from Asian ports to Northern European base ports, and four service loops from Asian ports to Mediterranean ports every week. The majority of the fleet operated in these total twelve loops will be ranging from 8,000TEU to 13,000TEU sizes.

Through this cooperation, CKYH-the Green Alliance and Evergreen will be able to provide the highest quality services to their customers with the shortest transit time from major origin ports to European destinations.

CKYH-the Green Alliance is also going to revamp its strategy to further consolidate their operations in rationalization of the services on the East/West direction, the development of the North/South routes, the development of niche markets, utilization of assets such as vessels and terminals, cutting the costs for servicing the equipment, and the feeder network and the contracts with the intermediary companies.

\subsection{The Tie-Up of CKYHE Alliance}

In February 2014, non-conference Evergreen Line (Taiwan) joined CKYH Alliance as the new member redubbing CKYH as CKYHE. CKYHE provides six Asia-North Europe services and three Asia-Mediterranean services with the optimum port coverage throughout Asia, North Europe, East Mediterranean, West Mediterranean and Adriatic region from early April of 2015.

With an aim to enhancing its services, On October 21, 2014, CKYHE announced that they will expand their cooperation (vessel-sharing agreement) covering the Transpacific and Transatlantic trade lanes and filed an agreement and reports to related regulators to comply with their regulations.

Regarding the expansion of the cooperation, CKYHE has already submitted a formal letter to Ministry of Transport (MOT) of PRC, filed with the U.S. FMC (Federal Maritime Commission) a "Filing Agreement" covering U.S. trades, and informed the EU Commission of developments. And in December 2014, the above mentioned CKYHE's new services were all approved.

On Transpacific trade lane, CKYHE will follow the same pattern of cooperation that the alliance members have successfully applied in the Asia/North Europe and Asia/Mediterranean trades lanes during the past year. This 
expanded cooperation will provide the carriers with greater operational flexibility and will permit each of them to better serve its customers, offering wider port coverage, increased frequency of sailings and stable transit times.

Each line of CKYHE is committed to environment-friendly shipping; enhancing service efficiency, providing stable transit time and offering more flexible port-pair options. After the regulators approve, the parties will discuss and agree their cooperation with a target implementation date of the spring 2015.

\subsection{The Formation of G6 Alliance}

With an aim to competing with CKYH and sharing more pieces of a pie in the shipping market, in December 2012, the G6 Alliance was allied by the New World and Grand Alliances. New World Alliance members are APL (American President Line), Singapore; Hyundai Merchant Marine, Korea; and MOL (Mitsui O.S.K Lines), Japan, while Grand Alliance members are Hapag-Lloyd, Germany; NYK (Nippon Yusen Kaisha), Japan; and OOCL (Orient Overseas Container Line), Hong Kong.

The groundbreaking cooperation between said six ship owners is because they are able to load the container ship with more cargoes based on the consideration of improving loadability. The new partnership will create one of the leading networks in the Asia/Europe and Asia/Mediterranean trade lanes with more than 90 ships in nine services calling at more than 40 ports in Asia, Europe and the Mediterranean. G6 enables service features to be easily adjusted to market requirements.

The services provided by G6 are the milestone agreements that significantly improve service coverage in the Asia/Europe trade lane which offers sailing frequencies and direct coverage that can compete with any other alliance in the market.

In early March 2012, G6 began operation with seven joint services operating between Asia and Europe and two services to the Mediterranean. It includes a direct Far East/Baltic service calling at Gdansk, Poland and Gothenburg, Sweden as well as transhipment in Singapore. G6 is characterized by fast transit times, broad port coverage and the latest vessels, with capacities of up to 14,000 TEUs. And in May 2013, G6 extended joint services coverage in Asia/ North America East Coast trade lane.

With a target to extending its service coverage, In April 2014, G6 successfully began operation on Asia/North America West Coast and Asia/trans-Atlantic trade lanes. G6 has been quite aggressive in market services, in response to market demand, in June 2015 G6 began enhancing its Asia/Europe trade lane service by improving transit time and coverage (Note 16).

\subsection{The Failure of P3 Alliance}

In June 2013, The world's three largest container shipping lines - Maersk (Denmark), MSC (Swiss) and CMA CGM (France) announced an operational alliance on three of the world busiest trade lanes - Asia/north America, Asia/Europe and Transatlantic in a sign of tough conditions facing the sector, dubbed the P3 Network. This is a further-step alliance since the services cooperation on Asia/North America trade lane in 2008.

P3 will be an independently operated network pool vessels equivalent to 15 percent of global capacity comprising 255 vessels totalling a capacity of 2.6millionTEUs. Its shipping routes will cover the Asia/Europe, Transpacific and Transatlantic (North Europe and Mediterranean) trades and was set to commence operations in the second quarter of 2014.

P3 operates about 37 percent of total global container capacity. Maersk Line contributes more than 100 vessels, including its new Triple E class 13,500TEU (IMO calculation: 11,000TEUs), comprising a capacity of 1.1million TEUs, or 42 percent of total operations, while MSC contributing 34 percent of the capacity at 0.9 million TEUs and CMA CGM contributing 24 percent at 0.6 million TEUs.

A unique selling point for P3 is its Joint Vessel Operating Centre (JVOC) aimed at delivering maximum cost efficiency. The companies assure that the alliance can deliver more stable, frequent and flexible services, with CMA CGM citing the P3 Network's capacity to offer 8 weekly sailings between Asia and Northern Europe. Despite this unified approach, each company is still set to have fully independent sales, pricing, marketing and customer service functions.

However, on June 17, 2014, China's Ministry of Commerce (MOFCOM), following a review under China's merger control rules, refused approval for the proposed P3 joint venture (tie-up) despite approval from the US and the EU competition authorities. 
The reason for the refusal is that the proposed arrangement would integrate the market power of the parties and consolidate their operating network, eliminating effective competition between major competitors and raising entry barriers to the market. The rejection was only the second ever by MOFCOM since China passed its Anti-Monopoly Law (AML) in 2008.

\subsection{The Formation of $2 M$ Alliance}

Sooner after the refusal of the P3 tie-up by MOFCOM, in July 2014 Maersk Line and MSC by leaving out CMA CGM announced plans for a 10-year Vessel Sharing Agreement (VSA) on the Asia/Europe, Transpacific and Transatlantic trade lanes as the carriers strive to better utilize capacity in the wake of the failed bid to launch the P3 Network.

The VSA is referred to as $2 \mathrm{M}$ and replaces all existing vessel and slot purchase agreements that Maersk Line has in these trades. In October 2014, 2M's proposed joint venture service was confirmed and approved by the regulatory authority, the U.S. FMC which assisted the entry into effect of the tie-up between Maersk Line and MSC. The U.S. FMC is the only remaining jurisdiction where Maersk Line and MSC had to obtain formal approval. Thus, both parties can implement the tie-up as planned.

Triggered by the approval, 2M began operation in Asia/Europe, Transpacific and Transatlantic trade lanes since January 2015. With an aim to enhancing the extensive scope of the collaboration, in July, 2015 2M announced that it will expand its VSA on U.S. trade lanes connecting to Israel, Russia and Saudi Arabia after a 45-day review expired Thursday without U.S. FMC action.

It is estimated by U.S. FMC that $2 \mathrm{M}$ will have an estimated market share of 35 percent, 31 percent, and percent on Asia/Europe, Asia/Atlantic and Asia/Pacific trade lane respectively when beginning the operation.

\subsection{The Formation of $\mathrm{O} 3$ Alliance}

After the formation of 2M tie-up, CMA CGM quickly initiated talks with CSCL (China Shipping Container Lines), China, and UASC (United Arab Shipping Co.), Arab states of the Persian Gulf for being the alliance partners.

In September, 2014 the new alliance being dubbed as O3 (Ocean Three) deployed a combined total of 132 container ships in 14 joint services on the major East/West trade lanes. In this joint venture, CMA CGM deploys 73 ships of that total.

$\mathrm{O} 3$ is ranking third in capacity on Asia/Europe trade lane behind 2M and the CKYHE, but ahead of the G6. It will rank as the fourth largest VSA on the Transpacific trade lane. O3 controls a 20 percent share of the capacity deployed on Asia/Europe trade lane and 13 percent of the Transpacific trade lane.

The size of the vessels is ranging between 11,000 TEUs and 16,000 TEUs initially, and in 2015, vessels size is to be up to 19,000 TEUs. In 2014 CMA CGM deployed its three 16,000TEU vessel on the Asia/Europe trade lane and three more in 2015 when delivered. UASC and CSCL deploy 11 ships of 19,000 TEUs which were delivered in 2015. CMA CGM has already deployed 14,000TEUs vessels in a VSA with UASC and CSCL on the Asia-Middle East trade lane, which services routes to the Red Sea and Turkey. It also has slot-charter agreements with UASC and CSCL on the Asia-Europe trade.

O3 shares major transshipment hubs in Pusan, South Korea, Port Klang, Malaysia and Khor Fakkan,Sharjah in the U.A.E. O3 has opportunities to feeder markets in Indonesia, Thailand, Cambodia and Vietnam. In addition, CMA CGM has its major transshipment hubs in the Mediterranean in Tangier and Malta.

\section{References}

BBC News. Retrieved from http://www.bbc.com/news/business-27898675

Branch, A. (2007). Elements of Shipping. London, U.K.: Routledge.

CMA CGM. Retrieved from https://www.cma-cgm.com/news/1/cma-cgm-maersk-line-and-msc-to-establish-an-operational-alliance

CNBC. $\quad$ Retrieved http://www.cnbc.com/2013/11/01/maersk-cma-cgm-and-msc-to-form-ocean-shipping-alliance.html

from COCSO Group News. (2011, April 19).

Evergreen Line. Retrieved from http://www.evergreen-line.com/tuf1/jsp/TUF1_Html.jsp?page=TBN1_141021.jsp 
EVERSHED INTERNATIONAL. from http://www.eversheds.com/global/en/what/articles/index.page?ArticleID=en/Competition_EU_and_Regulatory/ Chinas_Ministry_of_Commerce_sinks_proposed_P3_shipping_joint_venture

Federal Maritime Commission. Retrieved from https://en.wikipedia.org/wiki/Federal_Maritime_Commission Global Liner Shipping. Retrieved from http://www.globallinershipping.com/

Guldogan, E. (n.d.). Port Operations and Container.

JNC Network. (2011, December 27). Tokyo.

JOC com. Retrieved from http://www.joc.com/maritime-news/container-lines/2m/2m-gets-us-regulatory-ok-expand-russia-israel-saudi-ara bia-trades_20150723.html

JOC com. Retrieved from http://www.joc.com/maritime-news/container-lines/cma-cgm/o3-alliance-came-together-quickly-after-2m-anno uncement-cma-cgm_20140909.html

Lemper, B. Z. (n.d.). Trends in Container Shipping. Bern, Switzerland: Peter Lang GmbH.

Lloyd's List. Retrieved from https://www.lloydslist.com/11/topic/p3-network/

Lloyd's List Maritime Asia. (1999, April). LLP.

Lorange, P. (2009). Shipping Strategy: Innovating for Success. Cambridge, England: Cambridge University Press.

Malaysia vs. Singapore: A new spin in the anti-complacency drive. (1997, January 17). Asiaweek, p. 20.

MSC com. Retrieved from http://www.joc.com/maritime-news/container-lines/evergreen-line/ckhye-alliance-gets-us-regulatory-blessing_2 0141204.html

MSC com. Retrieved from http://www.joc.com/maritime-news/container-lines/2m

NYK. Retrieved from http://www.nyk.com/english/release/3710/003943.html

OSRA of 1998. Retrieved from https://scmwiki2012.wordpress.com/o/ocean-shipping-reform-act-of-1998/

Pinder, D. S. (2004). Shipping and Ports in the Twenty-first Century. London, U.K.: Routledge.

(2001). The PSA Corporation Annual Report.

SHIPPINGWATCH. Retrieved from http://shippingwatch.com/carriers/Container/article7094001.ece

Terminal Management: with applications. Saarbrücken, Germany: VDM Verlag.

The Mover. Retrieved from http://www.themover.co.uk/international-news/2014/05/20/3p-alliance-gets-us-approval

The Wall Street Journal. http://www.wsj.com/articles/growing-shipping-alliances-are-straining-major-u-s-gateway-ports-1430733531

Wang, M. (1997). The Rise of International Trade and Global Logistics in East Asia: The Case Study Emphasizing Asian NIEs. Study of Shipping Economy, 31, Japan Society of Shipping Economics, 117-135.

Wang, M. (1999). The Knowledge of Global Logistics in East Asia. Bunrigaku. Kyoto, Japan.

Wang, M. (2003). The Status of East Asian Hub Ports in Global Logistics. Ports and Harbors. Ports \& Harbors International Association.

Wang, M. (2014). Global Logistics and Shipping Alliance. TENDODO.

Wang, M. (2014). The Global Logistics System in East Asia. TENDODO BOOKS.

Wood, D. B. (1995). International Logistics. New York, U.S.A: Chapman \& Hall.

World Top Container Port. (2009). Container Management.

\section{Notes}

Note 1. Sues Canal is an artificial sea-level waterway in Egypt, connecting the Mediterranean Sea and the Red Sea. Opened in November 1869 after 10 years of construction work, it allows transportation by water between Europe and Asia without navigation around Africa. After multiple enlargements, the canal is $193.30 \mathrm{~km}$ (120.11 mile) long, $24 \mathrm{~m}$ 
(79 feet) deep and 205 meters (673 feet) wide as of 2010. The canal is owned and maintained by the Sues Canal Authority (SCA) of Egypt. Under international treaty, it may be used "in time of war as in time of peace, by every vessel of commerce or of war, without distinction of flag.

Note 2. Also known as the Alexander Act. It was passed by the US Congress in 1916 to create the US Shipping Board. The bill was sponsored by Representative Joshua W. Alexander (D) of Missouri, who was Chairman of the House Merchant Marine Committee. The act signified the birth of the modern American merchant marine.

Note 3. An NVOCC is a common carrier that holds itself out to the public to provide ocean transportation, issues its own bills of lading or equivalent documents, but does not operate the vessels that transport cargo. Companies may obtain both licenses and may act in both capacities. The U.S. legal distinction between the two is that a freight forwarder acts as the agent of a principal (typically a shipper or consignee) and the NVOCC is a transportation company (carrier) that is physically responsible for the carriage of goods and acts as its own principal.

Note 4. Sherman Antitrust Act is a landmark federal statute on United States competition law passed by Congress in 1890. It prohibits certain business activities that federal government regulators deem to be anticompetitive, and requires the federal government to investigate and pursue trusts, companies, and organizations suspected of being in violation. It was the first federal statute to limit cartels and monopolies, and today still forms the basis for most antitrust litigation by the United States federal government. However, for the most part, politicians were unwilling to refer to the law until Theodore Roosevelt's presidency (1901-1909).

Note 5. The passage of the Shipping Act of 1984 brought about a major deregulatory change in the regulatory regime facing shipping companies operating in the U.S. foreign commerce. The subsequent passage of the Ocean Shipping Reform Act of 1998, with its further deregulatory amendments and modifications to the Shipping Act of 1984, represented another pro-market shift in shipping regulation.

Note 6. The United States Federal Maritime Commission (FMC) is an independent federal agency, based in Washington, D.C., responsible for the regulation of ocean-born transportation in the foreign commerce of the U.S. FMC Regulates certain activities of international shipping lines, marine terminals operators, and ocean transportation intermediaries (OTIs) who operate in the U.S. foreign commerce.

Note 7. FOB, used for trade shipment, is an initialism which pertains to the shipping of goods. Depending on specific usage, it may stand for Free On Board. FOB specifies which party (buyer or seller) pays for which shipment and loading costs, and/or where responsibility for the goods is transferred. The last distinction is important for determining liability for goods lost or damaged in transit from the seller to the buyer.

Note 8. Generally speaking, compared with Guarantee Contract System, the Deferred Rebate System it holds the binding force on shippers strongly. Today, it is the upmost method adopted by the Closed Conference organized by the European ship-owners in binding shippers.

Note 9. The subsequent passage of the Ocean Shipping Reform Act of 1998, with its further deregulatory amendments and modifications to the Shipping Act of 1984, represented another pro-market shift in shipping regulation.

Note 10. OSRA of 1998 was a long awaited reform that set into motion a transformation of the industry's common carrier system from a system in which all pricing is filed with the government and made public into a contract based system that allowed for pricing to remain confidential.

Note 11. The surcharge includes BAF (Bunker Adjustment Factor), CAF (Currency Adjustment Factor), YAS (Yen Appreciation Surcharge), THC (Terminal Handling Charge) etc.

Note 12. The size of the vessel is too large to pass through the Panama Canal. As of July 2015, the maximum beam width of the vessel which can traverse the Panama Canal is 32.3 meters.

Note 13. They are the space, like parking lot, under the deck of container vessel to keep empty and fully loaded containers. The slots, basically are divided into slots for TEU (Twenty Equivalent Unit), namely 20 -foot container and FEU (Forty Equivalent Unit), namely forty-foot container.

Note 14. Refer to COCSO Group News, April 19, 2011 for more details.

Note 15. JNC Network, Tokyo, Dec. 27, 2011 